\title{
Penerapan Metode Diskusi Pada Pembelajaran Muatan Matematika Sebagai Upaya Meningkatkan Hasil Belajar Peserta Didik di Kelas V SDN 98/X Rantau Indah Semester Ganjil Tahun Ajaran 2021/2022
}

\author{
Eka Wijayanti \\ SDN 98X Rantau Indah \\ Jl. Jenderal Ahmad Yani No. 6, Telanaipura, Jambi \\ eka_wijayanti@gmail.com
}

\begin{abstract}
This study aims to describe and obtain information on increasing the activity and learning outcomes of mathematics through the discussion method. This research is a classroom action research consisting of two cycles, each cycle consisting of two meetings. Each meeting consists of four stages, namely planning, implementation, observation and reflection. The subjects of this study were students of class V SDN 98/X Rantau Indah, totaling 18 people. This research was conducted in the odd semester of the 2021/2022 academic year. Data collection techniques using tests, observations, and documentation. Data were analyzed using percentages. The results showed that the discussion method could improve the learning outcomes of the fifth grade students of SDN 98/X Rantau Indah's mathematics content.
\end{abstract}

Keywords: Mathematics learning outcomes, Discussion

\begin{abstract}
Abstrak
Penelitian ini bertujuan untuk mendeskripsikan dan mendapatkan informasi peningkatan keaktifan dan hasil belajar matematika melalui metode diskusi. Penelitian ini merupakan penelitian tindakan kelas yang terdiri dari dua siklus masing-masing siklus terdiri dari dua kali pertemuan. Masing-masing petemuan terdiri dari empat tahapan yaitu perencanaan, pelaksanaan, observasi dan refleksi. Subjek penelitian ini adalah peserta didik kelas V SDN 98/X Rantau Indah yang berjumlah 18 orang. Penelitian ini dilaksanakan pada semseter ganjil tahun ajaran 2021/2022. Teknik pengumpulan data menggunakan tes, observasi, dan dokumentasi. Data dianalisis menggunakan persentase. Hasil penelitian menunjukkan bahwa melalui metode diskusi dapat meningkatkan hasil belajar muatan matematika peserta didik kelas V SDN 98/X Rantau Indah.
\end{abstract}

Kata kunci: Hasil belajar Matematika, Diskusi.

Copyright (c) 2022 Eka Wijayanti

Corresponding author: Eka Wijayanti

Email Address: eka_wijayanti@gmail.com (Jl. Sultan Thaha, Sido Mukti, Kec. Dendang, Jambi)

Received 10 January 2022, Accepted 20 January 2022, Published 17 Februari 2022

\section{PENDAHULUAN}

Pendidikan selalu mengalami perubahan, perkembangan dan perbaikan sesuai dengan perkembangan di segala bidang kehidupan. Perubahan dan perbaikan dalam bidang pendidikan meliputi berbagai komponen yang terlibat di dalamnya baik itu pelaksana pendidikan di lapangan (kompetensi guru dan kualitas tenaga pendidik), mutu pendidikan, perangkat kurikulum, sarana dan prasarana pendidikan dan mutu menejemen pendidikan termasuk perubahan dalam metode dan strategi pembelajaran yang lebih inovatif. Upaya perubahan dan perbaikan tersebut bertujuan membawa kualitas pendidikan Indonesia lebih baik.

Realitas saat ini, masih banyak peserta didik yang memiliki masalah dalam belajarnya dengan nilai-nilai yang selalu rendah dan tidak memiliki semangat dalam belajar yang baik. Sungguh ironi yang perlu dituntaskan sampai ke akar-akarnya. Peran orang tua juga harus ikut mendukung, di rumah peserta didik harus diajarkan kembali di pantau jangan sampai peserta didik hanya banyak bermain 
Penerapan Metode Diskusi Pada Pembelajaran Muatan Matematika Sebagai Upaya Meningkatkan Hasil Belajar Peserta Didik di Kelas V SDN 98/X Rantau Indah Semester Ganjil Tahun Ajaran 2021/2022, Eka Wijayanti

saja. Supaya peserta didik-siswi mendapatkan nilai yang tinggi dan memuaskan terutama dalam mata pelajaran Matematika.

Istilah mathematics (Inggris), mathematic (Jerman) atau mathematick/wiskunde (Belanda) berasal dari perkataan lain mathematica, yang mulanya diambil dari perkataan Yunani, mathematike, yang berarti relating to learning. Perkataan itu mempunyai akar kata mathema yang berarti pengetahuan atau ilmu (knowledge, science). Perkataan mathematike berhubungan sangat erat dengan sebuah kata lainnya yang serupa, yaitu mathematein yang mengandung arti belajar berpikir (Erman Suherman, 2003:18).

Matematika terdiri dari empat wawasan yang luas, yaitu: Aritmetika, Aljabar, Geometri dan Analisis. Selain itu matematika adalah ratunya ilmu, maksudnya bahwa matematika itu tidak bergantung pada bidang studi lain. Sementara menurut Depdiknas (2006: 346) bahwa matematika meliputi aspek-aspek bilangan, aljabar, geometri dan pengukuran serta statistika dan peluang. Senada dengan pendapat tersebut, James dan James dalam kamus matematikanya (Erman Suherman, 2003:16) mengatakan bahwa matematika adalah ilmu tentang logika mengenai bentuk, susunan, besaran, dan konsepkonsep yang berhubungan satu dengan yang lainnya dengan jumlah yang banyak yang terbagi kedalam tiga bidang, yaitu aljabar, analisis dan geometri.

Matematika adalah disiplin ilmu yang mempelajari tentang tata cara berpikir dan mengolah logika, baik secara kuantitatif maupun secara kualitatif (Erman Suherman, 2003:298). Menurut Johnson dan Rising dalam bukunya yang dikutip oleh Erman Suherman (2003:17) mengatakan bahwa matematika adalah pola berpikir, pola mengkoordinasikan, pembuktian yang logik, matematika itu adalah bahasa yang menggunakan istilah yang didefinisikan dengan cermat, jelas, dan akurat, presentasinya dengan simbol dan padat, lebih berupa bahasa simbol mengenai ide daripada mengenai bunyi.

Pendidikan tidak terlepas dari kegiatan pembelajaran. Belajar menurut Spears dalam Suprijono (2009:2) adalah mengamati, membaca, meniru, mencoba sesuatu, mendengar dan mengikuti arah tertentu. Jadi belajar adalah proses perubahan perilaku secara aktif, proses mereaksi terhadap semua situasi yang ada di sekitar individu, proses yang diarahkan kepada suatu tujuan, proses berbuat melalui berbagai pengalaman, proses melihat, mengamati, memahami sesuatu yang dipelajari.

Dalam proses belajar mengajar guru dituntut untuk dapat mewujudkan dan menciptakan situasi yang memungkinkan peserta didik untuk aktif dan kreatif. Pada sistem ini diharapkan peserta didik dapat secara optimal melaksanakan aktivitas belajar sehingga tujuan instruksional yang telah ditetapkan dapat tercapai secara maksimal.

Kegiatan belajar adalah kegiatan yang rumit karena tidak sekedar menyerap informasi dari guru, tetapi melibatkan berbagai kegiatan maupun tindakan yang harus dilakukan terutama jika diinginkan hasil yang baik. Salah satu pembelajaran yang menekankan berbagai tindakan adalah menggunakan metode tertentu dalam pembelajaran. Pendekatan dalam pembelajaran merupakan suatu 
upaya dalam mengembangkan keaktifan belajar. Saat ini khususnya guru di SDN 98/X Rantau Indah masih menggunakan metode pembelajaran konvensional dimana guru menerangkan dan murid hanya mendengarkan penjelasan guru serta mencatat, sehingga di SDN 98/X Rantau Indah perlu diterapkan metode pembelajaran kooperatif atau berdiskusi.

Untuk mengatasi masalah yang berkelanjutan maka perlu diterapkan metode pembelajaran yang tepat sehingga dapat meningkatkan keaktifan peserta didik dalam pembelajaran matematika. Metode tersebut adalah metode pembelajaran diskusi. Metode diskusi merupakan metode yang membuat para peserta didik aktif karena semua peserta didik memperoleh kesempatan berbicara atau berdialog satu sama lain untuk bertukar pikiran dan informasi tentang suatu topik atau masalah, atau mencari kemungkinan fakta dan pembuktian yang dapat digunakan bagi pemecahan suatu masalah. Dengan menggunakan metode diskusi dalam proses belajar mengajar matematika diharapkan agar peserta didik lebih aktif dalam belajar, sehingga peserta didik lebih bergairah dan bersemangat dalam mempelajari matematika serta dapat mengaplikasikan dalam kehidupan sehari-hari.

Pada zaman modern diskusi telah dianggap sebagai salah satu cirri penting sebuah kelas yang demokratis, yang didefinisikan sebagai suatu kegiatan di mana orang-orang berbicara bersama untuk berbagi dan saling tukar informasi tentang sebuah topic atau masalah atau mencari pemecahan terhadap suatu masalah berdasarkan bukti-bukti yang ada. (Abdul Azis, 2007: 100). Selama ini telah terjadi kecenderungan dalam memberikan makna mutu pendidikan yang hanya dikaitkan dengan aspek kemampuan kognitif. Pandangan ini telah membawa akibat terabaikannya aspek-aspek moral, akhlak, budi pekerti, seni, psikomotor, serta life skill. Dengan diterbitkannya Undang-undang Nomor 20 Tahun 2003 tentang Sistem Pendidikan Nasional dan Peraturan Pemerintah Nomor 19 Tahun 2005 tentang Standar Nasional Pendidikan akan memberikan peluang untuk menyempurnakan kurikulum yang komprehensif dalam rangka mencapai tujuan pendidikan nasional.

Berdasarkan atas evaluasi peneliti selama mengajar di kelas V SDN 98/X Rantau Indah, terdapat beberapa kendala dalam pencapaian hasil belajar yang optimal. Dari beberapa kali diberikan penilaian ternyata hasil belajarnya masih tetap rendah walau telah diberikan berbagai metode atau metode pembelajaran, yang menjadi bidang kajian peneliti ini adalah rendahnya hasil belajar peserta didik untuk mata pelajaran Matematika di kelas V SDN 98/X Rantau Indah. Untuk meningkatkan hasil belajar peserta didik tersebut secara maksimal, maka perlu perbaikan metode pembelajaran yaitu melalui Metode Pembelajaran Diskusi. Metode diskusi yaitu untuk melatih murid agar mengembangkan ide-ide dan melatih kepercayaan diri agar berani mengutarakan pendapatnya di hadapan umum. Memecahkan masalah secara bersama dengan menghargai pendapat orang lain. Penelitian ini dilakukan untuk memecahkan masalah yang selama ini menyebabkan guru resah, gelisah dengan banyaknya nilai peserta didik tidak tuntas sesuai dengan nilai ketuntasan minimal (KKM). Padahal guru selama ini telah menerapkan yang namanya Pembelajaran kontekstual, dimana pusat pembelajaran sudah berada pada peserta didik dan guru hanya sebagai pemotifator dan fasilitator. 
Penerapan Metode Diskusi Pada Pembelajaran Muatan Matematika Sebagai Upaya Meningkatkan Hasil Belajar Peserta Didik di Kelas V SDN 98/X Rantau Indah Semester Ganjil Tahun Ajaran 2021/2022, Eka Wijayanti

\section{METODE}

Jenis penelitian ini adalah penelitian tindakan kelas. Penelitian ini dilaksanakan di SDN 98/X Rantau Indah pada semester ganjil, tahun ajaran 2021/2022. Subjek dalam penelitian ini adalah siswa V dengan jumlah peserta didik 18 orang. Prosedur penelitian ini meliputi perencanaan, pelaksanaan, pengamatan, dan refleksi. Penelitian ini dilaksanakan dalam dua siklus, masing-masing siklus terdiri dari dua kali pertemuan. Teknik yang digunakan dalam pengumpulan data adalah observasi, tes, catatan lapangan dan dokumentasi. Data dianalisis melalui persentase dan reduksi data.

\section{HASIL DAN DISKUSI}

\section{Siklus I}

\section{Perencanaan}

Penerapan metode diskusi untuk meningkatkan aktivitas belajar peserta didik berpedoman dari langkah-langkah penelitian yang dirumuskan dalam prosedur penelitian. aktivitas yang dilakukan antara lain membuat jadwal penelitian tindakan kelas. Kemudian menentukan materi yang akan dilaksanakan pada waktu penelitian agar mengetahui kompetensi dasar yang akan disampaiakan kepada peserta didik dalam pembelajaran. Selain itu mempersiapkan silabus, mempersiapkan rencana pelaksaan pembelajaran dengan mengacu pada tindakan yang diterapkan dalam PTK. Terakhir menyiapkan media yang akan dipakai pada saat penelitian dan membagi peserta didik dalam beberapa kelompok.

\section{Pelaksanaan}

Pertemuan pertama siklus I dilakukan pada hari Senin, 11 Oktober 2021 dengan KD Mengenal konsep perpangkatan dan penarikan akar bilangan pangkat dua dan bilangan pangkat tiga sederhana, kemudian menuliskan perpangkatan dua sebagai perkalian berulang. Lalu menentukan bilangan yang tidak diketahui dalam persamaan yang melibatkan penambahan, pengurangan, perkalian, atau pembagian bilangan satu atau dua angka. Selain itu menyelesaikan permasalahan matematika yang melibatkan perkalian. Langkah selanjutnya adalah melaksanakan tindakan skenario pembelajaran sesuai dengan yang telah di rencanakan bersama kolaborator untuk setiap siklus tindakan yang dilakukan mengikuti tahapan sebagai berikut. Tahapannya terdiri dari kegiatan pendahuluan, inti, dan penutup.

Pada kegiatan pendahuluan ini Peserta didik merespon salam dan pertanyaan dari guru berhubungan dengan kondisi dan pembelajaran sebelumnya. Guru mengajak semua peserta didik berdo'a menurut agama dan keyakinan masing-masing, dilanjutkan dengan Pembacaan Teks Pancasila. Guru membuka pelajaran dengan sesuatu yang menarik perhatian peserta didik, seperti bercerita, bertanya jawab, bernyanyi, bertepuk dinamika, melakukan permainan, mendemonstrasikan sesuatu, memberikan masalah dan sebagainya. Peserta didik menerima informasi tentang keterkaitan pembelajaran sebelumnya dengan 
menerima informasi kompetensi, meteri, tujuan, manfaat, dan langkah pembelajaran yang akan dilaksanakan.

Pada kegiatan inti ini peserta didik dibentuk dalam 4 kelompok, Peserta didik membaca dialog singkat yang menjembatani peristiwa konstekstual yang terjadi dalam kehidupan sehari-hari mereka dengan konsep matematika. Peserta didik berdiskusi dan mengamati penjelasan tentang bilangan perpangkatan dua pada buku teks. Peserta didik menggunakan penalarannya untuk mencari keterkaitan konsep matematika bilangan perpangkatan dua dengan permasalahan sehari-hari. Peserta didik menguji pemahamannya dengan memecahkan beberapa soal matematika yang disajikan di buku peserta didik. Peserta didik mengkomunikasikan pemahamannya tentang bilangan perpangkatan dua dan kaitannya dengan perkalian yang berulang melalui soal-soal cerita matematika. Peserta didik menuliskan hal-hal yang sudah dipelajarai, pahami dan lakukan. Peserta didik menggunakan format refleksi yang disediakan pada buku peserta didik. Guru membimbing diskusi peserta didik supaya peserta didik bisa menuliskan secara detil apa saja kegiatan yang sudah dilakukan dan hal-hal yang sudah mereka pahami.

Pada kegiatan penutup ini Peserta didik bersama guru menyimpulkan pembelajaran. Peserta didik melakukan refleksi terhadap kegiatan yang sudah dilakukan. Peserta didik diberikan kesempatan berbicara/bertanya dan menambahkan informasi dari peserta didik lainnya. Guru menyampaikan pesan moral pembelajaran hari ini. Peserta didik menyimak informasi mengenai rencana tindak lanjut pembelajaran. Salam dan do'a penutup. Sebagai bentuk komunikasi dengan orang tua/wali: Guru meminta orang tua/wali membaca dan menandatangani hasil tugas peserta didik. Lalu, guru memberikan informasi secepatnya, bilamana anaknya bermasalah dalam belajar di kelas.

Pertemuan pertama siklus I dilakukan pada hari Senin, 18 Oktober 2021 dengan KD Mengenal konsep perpangkatan dan penarikan akar bilangan pangkat dua dan bilangan pangkat tiga sederhana, kemudian menuliskan perpangkatan dua sebagai perkalian berulang . Lalu menentukan bilangan yang tidak diketahui dalam persamaan yang melibatkan penambahan, pengurangan, perkalian, atau pembagian bilangan satu atau dua angka. Selain itu menyelesaikan permasalahan matematika yang melibatkan perkalian. Langkah selanjutnya adalah melaksanakan tindakan skenario pembelajaran sesuai dengan yang telah di rencanakan bersama kolaborator untuk setiap siklus tindakan yang dilakukan mengikuti tahapan sebagai berikut. Tahapannya terdiri dari kegiatan pendahuluan, inti, dan penutup.

Pada kegiatan pendahuluan ini Peserta didik merespon salam dan pertanyaan dari guru berhubungan dengan kondisi dan pembelajaran sebelumnya. Guru mengajak semua peserta didik berdo'a menurut agama dan keyakinan masing-masing, dilanjutkan dengan Pembacaan Teks Pancasila. Guru membuka pelajaran dengan sesuatu yang menarik perhatian peserta didik, seperti bercerita, bertanya jawab, bernyanyi, bertepuk dinamika, melakukan permainan, mendemonstrasikan sesuatu, memberikan masalah dan sebagainya. Peserta didik menerima informasi tentang keterkaitan pembelajaran sebelumnya dengan pembelajaran yang akan dilaksanakan. Selain itu peserta didik 
Penerapan Metode Diskusi Pada Pembelajaran Muatan Matematika Sebagai Upaya Meningkatkan Hasil Belajar Peserta Didik di Kelas V SDN 98/X Rantau Indah Semester Ganjil Tahun Ajaran 2021/2022, Eka Wijayanti

menerima informasi kompetensi, meteri, tujuan, manfaat, dan langkah pembelajaran yang akan dilaksanakan.

Pada kegiatan inti ini peserta didik dibentuk dalam 4 kelompok, Peserta didik membaca dialog singkat yang menjembatani peristiwa konstekstual yang terjadi dalam kehidupan sehari-hari mereka dengan konsep matematika. Peserta didik berdiskusi dan mengamati penjelasan tentang bilangan perpangkatan dua pada buku teks. Peserta didik menggunakan penalarannya untuk mencari keterkaitan konsep matematika bilangan perpangkatan dua dengan permasalahan sehari-hari. Peserta didik menguji pemahamannya dengan memecahkan beberapa soal matematika yang disajikan di buku peserta didik. Peserta didik mengkomunikasikan pemahamannya tentang bilangan perpangkatan dua dan kaitannya dengan perkalian yang berulang melalui soal-soal cerita matematika. Peserta didik menuliskan hal-hal yang sudah dipelajarai, pahami dan lakukan. Peserta didik menggunakan format refleksi yang disediakan pada buku peserta didik. Guru membimbing diskusi peserta didik supaya peserta didik bisa menuliskan secara detil apa saja kegiatan yang sudah dilakukan dan hal-hal yang sudah mereka pahami.

Pada kegiatan penutup ini Peserta didik bersama guru menyimpulkan pembelajaran. Peserta didik melakukan refleksi terhadap kegiatan yang sudah dilakukan. Peserta didik diberikan kesempatan berbicara/bertanya dan menambahkan informasi dari peserta didik lainnya. Guru menyampaikan pesan moral pembelajaran hari ini. Peserta didik menyimak informasi mengenai rencana tindak lanjut pembelajaran. Salam dan do'a penutup. Sebagai bentuk komunikasi dengan orang tua/wali: Guru meminta orang tua/wali membaca dan menandatangani hasil tugas peserta didik. Lalu, guru memberikan informasi secepatnya, bilamana anaknya bermasalah dalam belajar di kelas.

\section{Observasi}

Sesuai dengan tujuan peneliti yang telah dikemukakan sebelumnya yaitu untuk meningkatkan aktivitas belajar peserta didik pada pembelajaran Matematika melalui penerapan metode diskusi dikelas V SDN 98/X Rantau Indah dengan indikator belajar peserta didik yaitu: Mengerjakan tugas kelompok, Bertanya dalam kelompok, Menjawab Pertanyaan, Menanggapi tugas kelompok. Distribusi persentase frekuensi hasil belajar dapat dilihat dari hasil analisis data pada tabel berikut.

Tabel 1. Rekapitulasi hasil tes formatif Siklus I

\begin{tabular}{|c|c|c|}
\hline No & Uraian & Hasil \\
\hline 1 & Jumlah Nilai & 1220 \\
\hline 2 & Rata-rata Nilai & 67.78 \\
\hline 3 & Peserta didik Tuntas & 11 \\
\hline 4 & Peserta didik Tidak Tuntas & 7 \\
\hline 5 & Persentase Peserta didik Tuntas & $61 \%$ \\
\hline 6 & Persentase Peserta didik Tidak Tuntas & $39 \%$ \\
\hline
\end{tabular}


Berdasarkan tabel 1. dapat dilihat bahwa rata-rata nilai yang didapat dari hasil tes formatif siklus I sebesar 67,78, dan dari hasil observasi hasil belajar peserta didik pada siklus I yang tuntas sebanyak 11 orang atau sebesar $61 \%$. Oleh karena itu dapat dilihat bahwa hasil belajar peserta didik pada setiap pertemuan mengalami peningkatan namun belum mencapai target yang ditentukan yaitu sebesar $85 \%$.

\section{Refleksi}

Berdasarkan hasil analisis data observasi bersama guru mitra sebagai obsever yaitu Elly Siahaan, S.Pd. yang dilakukan pada hari Jumat, tanggal 22 Oktober 2021 yang dilakukan di kantor majelis guru, dapat disimpulkan refleksi pada siklus I, dengan dua kali pertemuan bahwa penggunaan metode diskusi dalam bentuk kerja kelompok dan tanya jawab cukup mempengaruhi hasil belajar peserta didik. tahun pelajaran.

Setelah dilihat dari semua indikator yang dikemukakan dari penelitian secara total belum mencapai target yang di inginkan artinya jumlah peserta didik yang tuntas masih di bawah $85 \%$, namun ada beberapa kelemahan yang di temukan pada siklus I. Pertama sekali sifat malas pada diri peserta didik, kurangnya buku sumber yang dipakai peserta didik dan hanya mengandalkan rangkuman materi yang diberikan oleh guru. Masih banyak peserta didik yang belum aktif dimana yang bertanya dan mengerjakan tugas hanya orang-orang tetap yang itu saja terutama pada indikatorindikator aktivitas tertentu hal ini diakibatkan oleh adanya rasa malu terhadap teman sekelas dan tidak percaya diri atau takut salah dalam mengemukakan pendapat di depan teman-temannya, ini karna semua kebiasaan peserta didik yang masih mendapat materi hanya tertumpu pada metode ceramah dari guru.

Berdasarkan kelemahan-kelemahan yang ditemukan dalam siklus I maka perlu dicarikan solusi dengan melakukan revisi terhadap tindakan yang dilakukan antara lain: 1) pertama sekali guru harus merubah pandangan peserta didik terhadap penyampaian materi yang tertumpu pada ceramah dari guru saja 2) Guru membimbing peserta didik untuk merumuskan pertanyaan, menjawab dan berpendapat, sehingga relevan dengan materi yang didiskusikan. Oleh karena itu guru diharapakan mampu untuk mengatasi kekurangan waktu harus bisa mengatur jalannya diskusi agar tidak larut dalam satu pertanyaan atau tanggapan yang relevan, mempersiapkan hadih bagi peserta didik yang paling aktif bertanya dalam berdiskusi. Oleh karena itu penelitian ini dilanjutkan ke siklus berikutnya.

\section{Siklus II}

\section{Perencanaan}

Pelaksanaan metode diskusi untuk meningkatkan hasil belajar peserta didik berpedoman dari langkah-langkah penelitian yang dirumuskan dalam prosedur penelitian. aktivitas yang dilakukan antara lain membuat jadwal lanjutan penelitian tindakan kelas, menentukan materi lanjutan dari siklus I yang akan dilaksanakan pada waktu penelitian pada siklus II agar mengetahui kompetensi dasar yang akan disampaiakan kepada peserta didik dalam pembelajaran. Selain itu mempersiapkan silabus. 
Penerapan Metode Diskusi Pada Pembelajaran Muatan Matematika Sebagai Upaya Meningkatkan Hasil Belajar Peserta Didik di Kelas V SDN 98/X Rantau Indah Semester Ganjil Tahun Ajaran 2021/2022, Eka Wijayanti

Kemudian Mempersiapkan rencana pelaksanaan pembelajaran lanjutan dengan mengacu pada tindakan yang diterapkan dalam PTK, Menyiapkan media yang akan dipakai pada saat penelitian, Membagi peserta didik dalam beberapa kelompok, dan Menyiapkan reward/hadiah.

\section{Pelaksanaan}

Pertemuan pertama dilakukan pada hari Senin, 25 Oktober 2021 dengan KD Mengenal konsep perbandingan dan skala, Menjelaskan perbandingan, Memecahkan masalah sederhana yang melibatkan perbandingan. Selain itu KD pada siklus II ini adalah dapat merumuskan dengan kalimat sendiri, membuat model matematika, dan memilih strategi yang efektif dalam memecahkan masalah nyata sehari-hari yang berkaitan dengan konsep perbandingan, skala, dan hubungan antar kuantitas, serta memeriksa kebenaran jawabnya. Kemudian menuliskan model matematika dari masalah yang berkaitan dengan konsep perbandingan. Menerapkan strategi yang tepat untuk menyelesaikan masalah yang berkaitan dengan konsep perbandingan. Selain itu memeriksa kebenaran jawaban dalam menyelesaikan masalah yang berkaitan dengan konsep perbandingan.

Peserta didik merespon salam dan pertanyaan dari guru berhubungan dengan kondisi dan pembelajaran sebelumnya. Guru mengajak semua peserta didik berdo'a menurut agama dan keyakinan masing-masing, dilanjutkan dengan Pembacaan Teks Pancasila. Guru membuka pelajaran dengan sesuatu yang menarik perhatian peserta didik, seperti bercerita, bertanya jawab, bernyanyi, bertepuk dinamika, melakukan permainan, mendemonstrasikan sesuatu, memberikan masalah dan sebagainya. Peserta didik menerima informasi tentang keterkaitan pembelajaran sebelumnya dengan pembelajaran yang akan dilaksanakan. Peserta didik menerima informasi kompetensi, meteri, tujuan, manfaat, dan langkah pembelajaran yang akan dilaksanakan.

Peserta didik dibentuk dalam beberapa kelompok. Peserta didik melakukan diskusi tentang bagaimana sebuah barang ditawarkan dan dipasarkan (guru memberi bimbingan dan mengarahkan diskusi ke topik pembicaraan tentang iklan). Peserta didik mencermati dan memahami cara menuliskan perbandingan harga dua telepon genggam yang tertulis pada buku peserta didik. Peserta didik memahami berbagai kemungkinan perbandingan jika diketahui harga dua telepon genggam. Peserta didik menghitung banyak peserta didik laki-laki dan perempuan di kelasnya, lalu menuliskan perbandingan-perbandingan yang diminta dalam tabel.

Pada kegiatan penutup ini peserta didik bersama guru menyimpulkan pembelajaran. Peserta didik melakukan refleksi terhadap kegiatan yang sudah dilakukan. Peserta didik diberikan kesempatan berbicara/bertanya dan menambahkan informasi dari peserta didik lainnya. Guru menyampaikan pesan moral pembelajaran hari ini. Peserta didik menyimak informasi mengenai rencana tindak lanjut pembelajaran. Salam dan do'a penutup. Bentuk komunikasi dengan orang tua/wali: Guru meminta orang tua/wali membaca dan menandatangani hasil tugas peserta didik. Guru memberikan informasi secepatnya, bilamana anaknya bermasalah dalam belajar di kelas.

Pertemuan kedua dilakukan pada hari Senin, 1 November 2021 dengan KD Mengenal konsep perbandingan dan skala, Menjelaskan perbandingan, Memecahkan masalah sederhana yang 
melibatkan perbandingan. Selain itu KD pada siklus II ini adalah dapat merumuskan dengan kalimat sendiri, membuat model matematika, dan memilih strategi yang efektif dalam memecahkan masalah nyata sehari-hari yang berkaitan dengan konsep perbandingan, skala, dan hubungan antar kuantitas, serta memeriksa kebenaran jawabnya. Kemudian menuliskan model matematika dari masalah yang berkaitan dengan konsep perbandingan. Menerapkan strategi yang tepat untuk menyelesaikan masalah yang berkaitan dengan konsep perbandingan. Selain itu memeriksa kebenaran jawaban dalam menyelesaikan masalah yang berkaitan dengan konsep perbandingan.

Peserta didik merespon salam dan pertanyaan dari guru berhubungan dengan kondisi dan pembelajaran sebelumnya. Guru mengajak semua peserta didik berdo'a menurut agama dan keyakinan masing-masing, dilanjutkan dengan Pembacaan Teks Pancasila. Guru membuka pelajaran dengan sesuatu yang menarik perhatian peserta didik, seperti bercerita, bertanya jawab, bernyanyi, bertepuk dinamika, melakukan permainan, mendemonstrasikan sesuatu, memberikan masalah dan sebagainya. Peserta didik menerima informasi tentang keterkaitan pembelajaran sebelumnya dengan pembelajaran yang akan dilaksanakan. Peserta didik menerima informasi kompetensi, meteri, tujuan, manfaat, dan langkah pembelajaran yang akan dilaksanakan.

Peserta didik dibentuk dalam beberapa kelompok. Peserta didik melakukan diskusi tentang bagaimana sebuah barang ditawarkan dan dipasarkan (guru memberi bimbingan dan mengarahkan diskusi ke topik pembicaraan tentang iklan). Peserta didik mencermati dan memahami cara menuliskan perbandingan harga dua telepon genggam yang tertulis pada buku peserta didik. Peserta didik memahami berbagai kemungkinan perbandingan jika diketahui harga dua telepon genggam. Peserta didik menghitung banyak peserta didik laki-laki dan perempuan di kelasnya, lalu menuliskan perbandingan-perbandingan yang diminta dalam tabel.

Pada kegiatan penutup ini peserta didik bersama guru menyimpulkan pembelajaran. Peserta didik melakukan refleksi terhadap kegiatan yang sudah dilakukan. Peserta didik diberikan kesempatan berbicara/bertanya dan menambahkan informasi dari peserta didik lainnya. Guru menyampaikan pesan moral pembelajaran hari ini. Peserta didik menyimak informasi mengenai rencana tindak lanjut pembelajaran. Salam dan do'a penutup. Bentuk komunikasi dengan orang tua/wali: Guru meminta orang tua/wali membaca dan menandatangani hasil tugas peserta didik. Guru memberikan informasi secepatnya, bilamana anaknya bermasalah dalam belajar di kelas.

\section{Observasi}

Sesuai dengan tujuan peneliti yang telah dikemukakan sebelumnya yaitu untuk meningkatkan hasilbelajar peserta didik pada muatan matematika melalui penerapan metode diskusi di kelas V SDN 98/X Rantau Indah. Distribusi persentase frekuensi hasil belajar dapat dilihat dari hasil analisis data pada tabel berikut. 
Tabel 2. Rekapitulasi hasil tes formatif Siklus II

\begin{tabular}{|c|c|c|}
\hline No & Uraian & Hasil \\
\hline 1 & Jumlah Nilai & 1415 \\
\hline 2 & Rata-rata Nilai & 78.61 \\
\hline 3 & Peserta didik Tuntas & 16 \\
\hline 4 & Peserta didik Tidak Tuntas & 2 \\
\hline 5 & Persentase Peserta didik Tuntas & $89 \%$ \\
\hline 6 & Persentase Peserta didik Tidak Tuntas & $11 \%$ \\
\hline
\end{tabular}

Berdasarkan tabel 2 diatas dapat dilihat bahwa ternyata hasil belajar meningkat, hal ini dapat dilihat dari rata-rata nilai yaitu 78,61 dan jumlah peserta didik yang tuntas sebesar 16 orang atau dengan persentase $89 \%$. Dari hasil observasi hasil belajar peserta didik pada siklus II dapat dilihat bahwa hasil belajar peserta didik pada setiap pertemuan mengalami peningkatan dan telah mencapai target ditentukan yaitu $85 \%$.

\section{Refleksi}

Berdasarkan hasil analisis data observasi bersama guru mitra sebagai obsever Elly Siahaan, S.Pd. yang dilakukan pada hari Jumat, tanggal 5 November 2021 yang dilakukan di kantor majelis guru dapat disimpulkan refleksi pada siklus II, dengan dua kali pertemuan bahwa penggunaan metode diskusi sangat mempengaruhi hasil belajar peserta didik. Hal ini dapat dilihat dari rekapitulasi pada siklus II hasil belajar meningkat menjadi $89 \%$, sudah melebihi dari target yang dikehendaki yaitu sebesar $85 \%$. Berdasarkan kelemahan-kelemahan yang ditemukan pada siklus II, maka perlu dicarikan solusi dengan melakukan revisi terhadap tindakan yang dilakukan antara lain: 1) Guru sudah berperan aktif memberi motivasi pada sebagian peserta didik yang masih memilki sifat malas, agar sifat tersebut bisa dihilangkan pada semua peserta didik, dengan memberikan penghargaan dan mengumumkan jumlah poin yang di kumpulkan tiap kelompok. 2) Guru sudah membimbing peserta didik untuk merumuskan pertanyaan, menjawab dan berpendapat, sehingga relevan dengan materi yang didiskusikan, 3) Guru sudah mampu untuk mengatasi kekurangan waktu harus bisa mengatur jalannya diskusi agar tidak larut dalam satu pertanyaan atau tanggapan yang relevan, 4) dikarenakan ada tindakan pemberian reward/hadiah bagi peserta didik yang paling aktif dalam bertanya. Oleh karena itu penelitian ini tidak dilanjutkan ke siklus berikutnya.

\section{Diskusi}

Dari temuan yang didapat pada siklus pertama dan siklus kedua berkaitan dengan aktivitas belajar peserta didik mengenai pembelajaran Matematika setelah menggunakan metode diskusi yang terdiri dari dua kali pertemuan berinti pada aspek-aspek yang di amati ternyata bahwa hasil belajar meningkat. Sementara itu rendahnya aktivitas peserta didik pada bertanya dalam kelompok berdasarkan peserta didik disebabkan oleh hal-hal di bawah ini : 1) beberapa peserta didik yang masih 
memiliki sifat malas mengikuti pelajaran atau rendahnya mental peserta didik untuk belajar 2) rendahnya kemampuan sisiwa memahami materi yang diberikan, 3) masih kurangnya kemampuan peserta didik mengemukakan ide dan pendapat, karena terpaku pada bahan ajar dari guru.

Pada temuan tersebut sesuai dengan pendapat Sudjana (2005) dimana pendapat tersebut berkesimpulan bahwa aktivitas belajar peserta didik mencakup dua hal yang tak terpisahkan. Yakni aktivitas mental ( emosional, intelektual, dan sosial), serta aktivitas motorik (gerak fisik) kedua aspek tersebut berkaitan antara yang satu dengan yang lainnya saling mengisi dan saling menetukan, oleh sebab itu keliru bila kita berpendapat bahwa optimalnya cara belajar peserta didik dilihat dari gerak motorik atau kegiatan mental semata-mata. Sementara itu peningkatan hasil belajar dapat dilihat pda grafik di bawah ini.

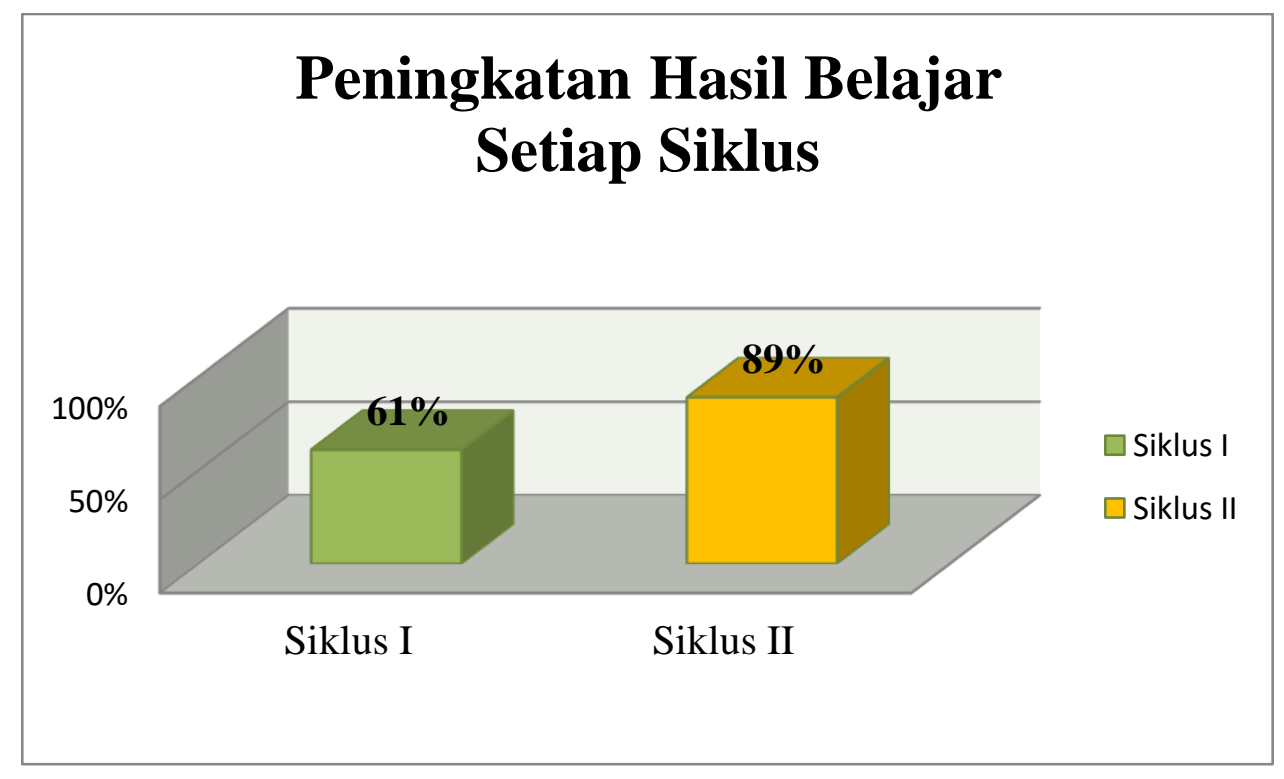

Gambar 1. Grafik peningkatan hasil belajar

\section{KESIMPULAN}

Dari hasil dan pembahasan di atas dapat ditarik kesimpulan bahwasanya Penerapan Metode Diskusi Pada Pembelajaran Muatan Matematika Sebagai Upaya Meningktkan Hasil Belajar Peserta Didik di Kelas V SDN 98/X Rantau Indah Semester Ganjil Tahun Ajaran 2021/2022, dapat dibuktikan berdasarkan tindakan yang dilakukan. Hasil pengamatan menunjukan bahwa hasil belajar peserta didik pada siklus I mencapai ketuntasan 61\%, meningkat pada siklus II menjadi 89\% dengan tindakan pemberian reward/hadiah. Dengan menggunakan metode diskusi dapat meningkatkan hasil belajar peserta didik dalam pembelajaran Matematika, peserta didik lebih bersemangat untuk belajar dan mendapatkan hasil yang lebih baik disetiap siklus.

Berdasarkan simpulan dan implikasi dari pembelajaran Matematika dengan menggunakan metode diskusi, maka dapat dikemukakan beberapa saran antara lain: Kepada guru kelas V SDN 98/X Rantau Indah disarankan agar dapat memahami dan merancang pembelajaran dengan menggunakan model-model pembelajaran yang inovatif. Kemudian kepada guru kelas V SDN 98/X Rantau Indah 
Penerapan Metode Diskusi Pada Pembelajaran Muatan Matematika Sebagai Upaya Meningkatkan Hasil Belajar Peserta Didik di Kelas V SDN 98/X Rantau Indah Semester Ganjil Tahun Ajaran 2021/2022, Eka Wijayanti

disarankan agar dapat melaksanakan proses pembelajaran Matematika dengan menggunakan metode diskusi, karena metode ini dapat meningkatkan hasil belajar peserta didik. Selain itu kepada lembaga terkait melalui pembinaan SD, disarankan hasil penelitian ini dapat dijadikan alternatif untuk memperbaiki proses pembelajaran dan pedoman untuk melanjutkan penelitian selanjutnya, agar mencapai hasil yang lebih maksimal.

\section{REFERENSI}

A.M, Sardiman. 2007. Interaksi dan Motivasi Belajar Mengajar. Jakarta: Raja. Grafindo Persada Asma, Nur. 2008. Metode Pembelajaran Kooperatif. Padang: UNP Press.

Azis Abdul Wahab (2007). Metode dan Metode-metode Mengajar. Bandung: Alfabeta

Bower, Gardner, Howard. 1987. Helping students think value strategies for teaching social studies.

Conny, Semiawan. 2008. Penerapan Pembelajaran Anak. Jakarta: Indeks

Engkoswara (1984). Dasar-dasar Metodologi Pengajaran. Bandung: Bina Aksara Jakarta.

Hamalik. 2008. Proses Belajar Mengajar. Bandung: Bumi Aksara.

Jalius Ellizar (2010). Pengembangan Program pembelajaran. Padang: Universitas Negeri Padang Press.

Jalius, Ellizar. 2009. Pengembangan Program Pembelajaran. Padang: UNP Press.

Maryani, Enok \& Kartawidjaja, Omi. 1996. Pengantar Geografi R egional. Jurusan Pendidikan Geografi FIPS. IKIP. Bandung.

Ngalimun, S.Pd. 2012. Strategi dan Metode Pembelajaran. Yogyakarta: Aswaja Pressindo

Purwanto, Ngalim. 2007. Psikologi Belajar. Jakarta: Raja Grafindo Persada.

Sardiman, A. dkk. 2003. Media Pendidikan, Pengertian, Pengembangan dan Pemanfatannya. Jakarta:

PT Raja Grafindo Persada.

Sudjana, Nana. 2004. Dasar-dasar Proses Belajar Mengajar. Bandung: Sinar. Baru Algensido Offset Sudjana, Nana. 2005. Penilaian Hasil Proses Belajar Mengajar, Bandung: PT Remaja Rosdikarya. Sugihartono, dkk, 2007. Psikologi Pendidikan. Yogyakarta: UNY Pers.

Suherman, Erman dkk. 2003. Strategi Pembelajaran Matematika Kontemporer. Bandung: PT Remaja Rosdakarya

Suryabrata, Sumadi. 1984. Psikologi Pendidikan. Jakarta: CV. Rajawali.

W.S. Winkel, 2009, Psikologi Pendidikan dan Evaluasi Belajar, Jakarta: Gramedia

Wina Sanjaya. 2009. Penelitian Tindakan Kelas. Jakarta: Kencana. 